\title{
Assessment of Municipal Solid Waste Landfilling Practices on the Ground Water Quality and Associated Health Risks: A Case Study of Mardan-Pakistan
}

\author{
Muhammad Israr \\ Pakistan Environmental Protection Agency \\ Shahla Nazneen ( $\sim$ shahlanaznin@uop.edu.pk) \\ University of Peshawar \\ Ali Raza \\ Rehman Medical College \\ Neelum Ali \\ University of Peshawar \\ Hizbullah Khan \\ University of Peshawar \\ Sardar Khan \\ University of Peshawar \\ Jawad Ali \\ BUITEMS: Balochistan University of Information Technology and Management Sciences
}

\section{Research Article}

Keywords: Total coliform, ground water, municipal solid waste, health risks

Posted Date: August 17th, 2021

DOI: https://doi.org/10.21203/rs.3.rs-723929/v1

License: (c) (i) This work is licensed under a Creative Commons Attribution 4.0 International License. Read Full License 


\section{Abstract}

This study was conducted to investigate the effects of municipal solid waste (MSW) used as landfilling on the ground water quality and health effects on the community. The study was carried out in Mardan, Khyber Pakhtunkhwa province- Pakistan. To assess the impacts, 13 ground water samples were collected from Solid Waste Dumping Sites (SWDS) and 13 from Safe Sites (SS). Ground water was analyzed for pH, Turbidity, Electrical Conductivity (EC), Total Hardness $(\mathrm{TH}), \mathrm{Cl}^{-}, \mathrm{Ca}^{+2}, \mathrm{~K}^{+1}, \mathrm{NO}^{-2}, \mathrm{NO}^{-3}, \mathrm{SO}_{4}{ }^{-2}$; heavy metals such as $\mathrm{Pb}, \mathrm{Cr}, \mathrm{Mn}, \mathrm{Cu}, \mathrm{Ni}, \mathrm{Zn}, \mathrm{Cd}$, Fe; biological parameter such as Total Coliform. Waste sample collected from SWDS showed that food and garden waste were present highest percentage by weight (30.5\%) followed by fines (17.3\%). The two groups (SWDS and SS) differ significantly for the parameters like $\mathrm{EC}, \mathrm{TH}, \mathrm{COD}, \mathrm{Na}, \mathrm{Ca}, \mathrm{NO}_{3}{ }^{-}$and $\mathrm{SO}_{4}{ }^{-2} \mathrm{Ni}$ and TC. Samples collected from SWDS

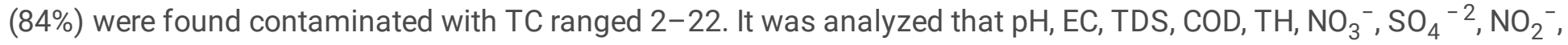
$\mathrm{Ca}^{+2}, \mathrm{Na}^{+}, \mathrm{TC}, \mathrm{Cr}, \mathrm{Ni}, \mathrm{Zn}, \mathrm{Cd}$ and TC were more in the sample collected from 70-130 feet than 140-200 feet. TC found in 70-80 feet depth was significantly different from rest of the groups. Similarly, significant difference regarding different parameters for various depths was found for $\mathrm{K}^{+1}, \mathrm{Ca}^{+2}, \mathrm{NO}_{2}{ }^{-}, \mathrm{Pb}, \mathrm{Cu}$ and Fe. The results of the questionnaire survey revealed negative correlation between the diseases and distance from the landfilling sites and significant correlation was observed for typhoid, cholera skin allergies and gastro enteritis. The study confirmed that using MSW as a fill material has contaminated the ground water quality and leveling of land through MSW is not safe. Deep drilling is recommended for extraction of ground water in the contaminated area to minimize the associated health risks.

\section{Introduction}

Water is an important factor of life sustainability on earth and without it, existence of life is not possible. Assessment and monitoring of water quality is important and variability of physicochemical parameters of drinking water quality are directly concerned with human health (Muhammad et al., 2010). Due to growing population, the demand for fresh water has increased throughout the world, especially in arid and semi-arid regions (Raju et al., 2011). The water quality on the other hand is getting deteriorated due to many factors and solid waste is one such factor. Solid waste has increased due to the increase in population and race to improve the living standards (Usmani et al., 2020). Solid wastes are classified into hazardous, clinical, municipal and radioactive waste while, municipal waste is characterized as domestic, industrial or institutional (Tang et al., 2020). The poor management of municipal and industrial effluents as well as solid waste contaminates the natural water resources because large amount of toxins along with other chemicals are mixed with water bodies when these waste come in contact with it (Leoni et al., 2005; Mishra et al., 2019). Predominantly in urban areas of developing countries, solid waste dumps pose great threats to the ground water source which is a key source of domestic water supply in these areas (Farid et al., 2012). Municipal solid waste dumps can contaminate the ground water resources with bacteria and other pathogens (Al-Sabahi et al., 2009). Generally MSW contains biological waste apart from paper, glass, plastic and metals (Mohsenizadeh et al., 2020) and the presence of different contaminants and coliform bacteria and other pathogens in drinking water indicate their contact with contamination (Farooq et al., 2008). A large variety of pathogens including coliform bacteria are present in the degraded material of MSW (Beffa et al., 1996). Further, presence of toxic heavy metals in MSW are also reported by literature which are carcinogenic in nature (IARC, 2018).

Pakistan is among the world's arid regions and most of the population is dependent on ground water to fulfill their water requirements for drinking and other domestic purposes. On the other hand, due to prevailing climatic conditions, water scarcity is increasing day by day. Pakistan has been listed among the countries that will have renewable water resources below the calculated threshold of $1500 \mathrm{~m}^{3} /$ capita/year by the year 2030 (Rijsberman, 2006). The 


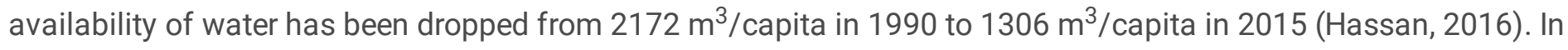
these circumstances protection of available water sources is of utmost importance for Pakistan. In Pakistan ground water quality has become a serious concern over the last few decades. Dependence on groundwater and indiscriminate usage has led to overexploitation of this resource. Moreover, threats to water contamination have been increased with the increase in population and industrialization (Khan et al., 2018). Lack of awareness among the general public regarding proper management of municipal solid waste further worsen the situation.

Mardan is one of the populous cities of Pakistan where population is dependent on ground water and in spite of all the above mentioned facts, in some regions of district Mardan, the locals are using municipal solid waste, preferably having high percentage of inert and earth particles, for leveling ups and downs of their residential lands without adopting any safety measures. Houses have already been constructed on such lands and hence best suited for identifying the impacts of MSW on ground water quality. This practice of the locals may pose threats to the ground water sources and ultimately to human health. Previously no research work has been carried out on this issue. Therefore, this research study was designed to assess the impacts of municipal solid waste landfill practices on ground water quality and associated health risk. Findings of this study will be beneficial for creating awareness in the countries where solid waste dumps are located near the water resources.

\section{Methodology Study area}

This study was conducted in the urban region of district Mardan which is the second most populous district of the Khyber Pakhtunkhwa province, Pakistan. It lays between latitude $34^{\circ} 05^{\prime}$ to $34^{\circ} 32^{\prime}$ North and longitude $71^{\circ} 48^{\prime}$ to $72^{\circ} 25^{\prime}$ East; located about $14 \mathrm{~km}$ northeast of Peshawar (Tufail et al., 2013). The study was focused on the small residential setting where most of the people were using MSW for leveling their residential lands. According to the TMA Mardan total estimated population of the area was 4000 to 5000 inhabitants; mostly belonged to middle class. Ground water is used for drinking and other domestic purposes in the area. Hand pumps and pressure pumps are used for extraction of ground water.

\section{Collection of waste samples at dumping sites}

Wastes from dumping sites which were not leveled yet and used for residential purpose were collected and analyzed through European commission methodology (user version 2004) and guidelines EPA, Ireland for MSW characterization to understand the types of wastes used for leveling of the ground.

\section{Samples collection}

Total 26 drinking water samples were collected from the study area. Samples were collected from SWDS $(n=13)$ and SS (n=13) (Fig. 1). Those areas where the locals have used municipal solid waste for leveling their residential lands were termed as Solid Waste Dumping Sites (SWDS) in this paper. While the areas where municipal solid waste was not used for leveling residential lands were termed as Safe Sites (SS). The SS was selected at least at $1000 \mathrm{~m}$ distance from the solid waste sites. All the samples were collected in 1.5 liters $(\mathrm{L})$ poly propylene bottles. The bottles were rinsed with 1:1 concentrated $\mathrm{HNO}_{3}$ and triple distilled water of Milli Q prior to use. The depth of the source was also recorded. The samples were taken from 70 to 200 feet depth. The samples were stored at $<08{ }^{\circ} \mathrm{C}$ and transferred to the laboratory within 04 hours for analysis. 


\section{Analysis of Physicochemical Parameters}

Ground water was analyzed for $\mathrm{pH}$, Turbidity, Electrical Conductivity (EC), Total Hardness (TH), $\mathrm{Cl}^{-}, \mathrm{Ca}^{+2}, \mathrm{~K}^{+1}, \mathrm{NO}^{-2}, \mathrm{NO}^{-}$

${ }^{3}, \mathrm{SO}_{4}{ }^{-2} \cdot \mathrm{pH}$, chlorides and hardness were measured with $\mathrm{pH}$ meter, Chloride test kit (Hanna 3815), hardness turbidity meter (HI96735 Hanna), respectively. $\mathrm{Ca}^{+2}, \mathrm{~K}^{+1}$ and $\mathrm{NO}^{-2}$ were measured with Hanna model No. HI83200, TDS with HI98129 and EC with HI98130 meters. Portable turbid meter (2100P ISO, Hach), sodium meter (HI 931101), nitrate meter (HI96786) and sulphate meter (HI76751 and HI38001) were used for the measurement of Turbidity, sodium, nitrate and sulphates, respectively. The permissible limits set by Pakistan, National Environmental Quality Standards'2010 (Pak-NEQS) were used for drinking water quality.

\section{Analysis of Heavy metals}

For analysis of selected heavy metals such as $\mathrm{Pb}, \mathrm{Cr}, \mathrm{Mn}, \mathrm{Cu}, \mathrm{Ni}, \mathrm{Zn}, \mathrm{Cd}$ and Fe were analyzed through atomic absorption spectrophotometer (Perkin Elmer AAS 700) as per American public health association (APHA), 1998 guidelines. The permissible limits set by Pakistan, National Environmental Quality Standards'2010 (Pak-NEQS) were used for drinking water quality for above mentioned parameters.

\section{Analysis of total Coliform}

Total Coliform tests were conducted using membrane filter method (method no. 9222-B) according to the procedure of American Public Health Association (APHA), 1998. Analytical grade chemicals and materials were used for analysis. The permissible limits set by Pakistan, National Environmental Quality Standards'2010 (Pak-NEQS) were used for drinking water quality for TC.

\section{Questionnaire Survey}

Questionnaire survey was conducted from 500 respondents living at different distance (living on the sites leveled by MSW (0-100m), 101-400 m, 401-700 m, 701-1000m) from the dumping sites. The age of the respondents ranged $15-$ 40 y and 250 males and 250 females were selected. Different diseases were selected from the literature including Diarrhea, Dysentery, Typhoid, Ringworm, Cholera, Malaria, any skin allergies, Gastro enteritis. The respondents were asked to select from any one option (Never, at least once in 2 months, once in 4 months, once in 6 months, once in a year and more than a year) against the mentioned diseases.

\section{Statistical analysis}

Statistical analyses and graphical representation of the data was conducted through SPSS v. 23. Pearson correlation was conducted to find out the relationship between depth and different parameters and to analyze the relationship between distance from the dumping sites and diseases. 


\section{Results And Discussion}

Waste sample collected from the solid waste dumping sites $(n=13)$ showed that food and garden waste were present highest percentage by weight (30.5\%) in the SWDS followed by fines (17.3\%). Beside these, paper and cardboard $(3.4 \%)$, glass $(3.7 \%)$, metals $(0.3 \%)$, plastics and rubber $(3.9 \%)$, wood $(2.7 \%)$, textile and rags $(3.7 \%)$, leather and nonrecyclable plastic $(5.9 \%)$, complex products $(4.2 \%)$, inert $(6.4 \%)$, healthcare waste $(2.2 \%)$ and other $(15.8 \%)$ constitutes the waste identified in the SWDS (Fig. 2).

\section{Physicochemical Parameters}

\section{Comparison between water samples taken from SWDS and SS}

Water samples collected from SWDS and SS showed that there was no significant difference in the mean values of $\mathrm{pH}$, turbidity, TDS, $\mathrm{Cl}^{-}, \mathrm{K}^{-}$and $\mathrm{NO}_{2}{ }^{-}$for both sites and $\mathrm{pH}, \mathrm{Cl}^{-}$and $\mathrm{NO}_{2}{ }^{-}$were within the permissible limit for all the sites (both SWDS and SS). Only 8\% and 31\% SWDS showed turbidity (range: 0.6-8.96 NTU) and TDS (range: 390$1206 \mathrm{mg} / \mathrm{L}$ ) beyond the permissible limit set by Pak-NEQS, respectively. While all the SS were within the limits for the above mentioned parameters (Table 1). The two groups (SWDS and SS) differ significantly for the parameters like EC, Total hardness, $\mathrm{COD}, \mathrm{Na}, \mathrm{Ca}, \mathrm{NO}_{3}{ }^{-}$and $\mathrm{SO}_{4}{ }^{-2}$. The $\mathrm{SS}$ showed these mentioned parameters within the permissible limit. But 54\%, 15\%, 15\%, 23\%, 8\% and 15\% SWDS showed that EC (Range: 705-2380 $\mu$ S/cm), Total hardness (range: 170-573), $\mathrm{Na}$ (range: 46-276), $\mathrm{Ca}$ (range 40-95), $\mathrm{NO}_{3}{ }^{-}$(range: 14-52) and $\mathrm{SO}_{4}{ }^{-2}$ (range: 89-376) were beyond the permissible limit (Table 1). The high value of EC is due to the high concentration of dissolved ions in the ground water and clearly indicates that leaching of waste has taken place from the landfill sites (Kumar and Alappat, 2005). The high value of COD in the SWDS samples indicate the high fraction of biodegradable waste (Somani et al., 2019). For

heavy metals, drinking water of SWDS and SS showed that $\mathrm{Pb}, \mathrm{Cu}, \mathrm{Zn}, \mathrm{Fe}, \mathrm{Mn}$ were within the permissible limit. While for Cr only $8 \%$ and for Ni 38\% drinking water samples for SWDS showed results beyond the permissible limit. The results for the Cd showed that $46 \%$ samples from SWDS and $38 \%$ SS were beyond the permissible limit. However, SWDS and SS differ significantly $(P<.05)$ for Ni only (Table 1$)$. 
Table 1

Results of water quality parameters collected from SWDS and SS

$\begin{array}{lllllllllll}\mathrm{pH} & \underset{(\mathrm{NTU})}{\mathrm{Turb}} & \underset{(\mu \mathrm{S} / \mathrm{cm})}{\mathrm{E} . \mathrm{C}} & \begin{array}{l}\mathrm{TDS} \\ (\mathrm{mg} / \mathrm{l})\end{array} & \mathrm{COD} & \mathrm{TH} & \mathrm{Na}^{+} & \mathrm{K}^{+} & \mathrm{Ca}^{+2} & \mathrm{SO}_{4}^{-2} & \mathrm{Cl}^{-}\end{array}$

\section{SWDS}

\begin{tabular}{|c|c|c|c|c|c|c|c|c|c|c|c|}
\hline Min. & 6.9 & 0.6 & 705 & 390 & 3 & 170 & 46 & 1.3 & 40 & 89 & 15.6 \\
\hline Max. & 8.2 & 8.96 & 2380 & 1206 & 15 & 573 & 276 & 7.6 & 95 & 376 & 147 \\
\hline Avg. & 7.54 & 2.33 & 1353.31 & 772.38 & 7.77 & 337.23 & 112.46 & 3.69 & 61.85 & 170.62 & 65.34 \\
\hline $\begin{array}{l}\text { St. } \\
\text { dev. }\end{array}$ & 0.41 & 2.20 & 596.66 & 295.09 & 3.68 & 141.18 & 68.91 & 1.82 & 16.52 & 83.64 & 45.34 \\
\hline
\end{tabular}

SS

\begin{tabular}{llllllllllll} 
Min. & 6.7 & 0.79 & 837 & 550 & 2 & 167 & 43 & 1.8 & 39 & 79 & 30.5 \\
\hline Max. & 8.2 & 2.2 & 1084 & 774 & 12 & 354 & 97 & 4.6 & 60 & 121 & 67.5 \\
\hline Avg. & 7.2 & 1.4 & 963.0 & 642.4 & 5.3 & 237.1 & 64.4 & 2.8 & 49.9 & 95.4 & 47.7 \\
\hline St. & 0.52 & 0.54 & 104.93 & 71.40 & 3.68 & 70.02 & 19.21 & 0.95 & 8.91 & 15.13 & 14.78
\end{tabular}

dev.

\begin{tabular}{|c|c|c|c|c|c|c|c|c|c|c|c|}
\hline NEQS & $\begin{array}{l}6.5- \\
8.5\end{array}$ & $<5$ & & $<1000$ & & 500 & 200 & 12 & 75 & 250 & 250 \\
\hline & $\mathrm{NO}_{3}{ }^{-}$ & $\mathrm{NO}_{2}^{-}$ & $\mathrm{Cr}$ & $\mathrm{Pb}$ & Cd & $\mathrm{Cu}$ & $\mathrm{Zn}$ & $\mathrm{Fe}$ & $\mathrm{Ni}$ & $\mathrm{Mn}$ & TC \\
\hline
\end{tabular}

\section{SWDS}

\begin{tabular}{llllllllllll} 
Min. & 14 & 0.00 & 0.00 & 0.00 & 0.00 & 0.00 & 0.00 & 0.00 & 0.00 & 0.00 & 22 \\
\hline Max. & 52 & 2.1 & 0.052 & 0.049 & 0.027 & 0.061 & 0.448 & 0.011 & 0.09 & 0.122 & 0 \\
\hline Avg. & 28.62 & 0.50 & 0.02 & 0.01 & 0.01 & 0.01 & 0.15 & 0.002 & 0.02 & 0.03 & 4.62 \\
$\begin{array}{l}\text { St. } \\
\text { dev. }\end{array}$ & 10.13 & 0.65 & 0.02 & 0.02 & 0.01 & 0.02 & 0.17 & 0.004 & 0.03 & 0.04 & 6.70 \\
\hline
\end{tabular}

SS

\begin{tabular}{lllllllllllll} 
Min. & 10.0 & 0.0 & 0.0 & 0.0 & 0.0 & 0.0 & 0.0 & 0.0 & 0.0 & 0.0 & 0.0 & 7 \\
Max. & 28 & 0.8 & 0.028 & 0.071 & 0.038 & 0.028 & 0.273 & 0.026 & 0 & 0.08 & 7 \\
\hline Avg. & 19.4 & 0.33 & 0.01 & 0.01 & 0.01 & 0.02 & 0.10 & 0.01 & 0.00 & 0.04 & 1.7 \\
$\begin{array}{l}\text { St. } \\
\text { dev. }\end{array}$ & 5.97 & 0.36 & 0.01 & 0.03 & 0.01 & 0.01 & 0.09 & 0.01 & 0.00 & 0.02 & 2.6 \\
\hline NEQS & $\mathbf{5 0}$ & $\mathbf{3}$ & $\mathbf{0 . 0 5}$ & $\mathbf{0 . 0 5}$ & $\mathbf{0 . 0 1}$ & $\mathbf{2}$ & $\mathbf{5}$ & & $\mathbf{0 . 0 2}$ & $\mathbf{0 . 5}$ &
\end{tabular}

Regarding TC results, $62 \%$ SWDS and $43 \%$ SS showed the sample were beyond the permissible limits. Contamination was recorded in the samples of both zones but the level of contamination was much higher in the samples of SWDS as compared to SS (Fig. 3). TC found in the samples of SWDS ranged 2-22. While only $43.3 \%$ of TC was found in the samples collected from SS that ranged 2-7. High percentage of TC as well as EC, Total hardness, $\mathrm{Na}, \mathrm{Ca}, \mathrm{NO}_{3}{ }^{-}$ 
and $\mathrm{SO}_{4}{ }^{-2}$ and $\mathrm{Ni}$ in the sample collected from SWDS indicates the possible percolation of leachate in the ground water from the solid waste landfills. These results are analogous to the findings of Mor et al. (2006) and Chonattu et al. (2016).

Samples collected from some areas of the safe zone also showed the presence of TC. Possible reason for this contamination may be the poor sanitary and hygiene conditions (Shar et al., 2008) as in some areas the same poor conditions were observed. However, comparatively higher concentration of TC and higher contamination percentage of SWDS samples indicates possible contamination of the ground water sources due to leachate percolation.

\section{Depth Wise Comparison Of Water Quality Parameters In Swds}

Water samples collected from various SWDS were collected from different depths. The depth where significant difference was found is given in Table 2. It is pertinent from the Table that TC found in 70-80 feet depth was significantly different from rest of the groups. Similarly, significant difference regarding different parameters for various depths was found for $\mathrm{K}^{+1}, \mathrm{Ca}^{+2}, \mathrm{NO}_{2}{ }^{-}, \mathrm{Pb}, \mathrm{Cu}$ and $\mathrm{Fe}$. The correlation found between depths and various parameters is given in Table 3. It is clear from the Table that most of the parameters are negatively correlated with the depths and as the depths increases the concentration of these parameters decreases. The level of ground water contamination due to MSW landfill or dumps depends upon various factors among which depth of the source is more prominent (Mor et al., 2006).

Table 2

Water quality parameters' relationship with depth

\begin{tabular}{|lllll|}
\hline Dependent Variable & Depths & Depths & Mean Difference (I-J) & Sig. \\
\hline $\mathrm{K}$ & $115-120$ & 160 & -2.82 & 0.03 \\
$\mathrm{Ca}$ & $70-80$ & 200 & 31.17 & 0.02 \\
$\mathrm{NO}{ }_{2}$ & $115-120$ & $130-140$ & 0.68 & 0.04 \\
$\mathrm{~Pb}$ & $70-80$ & $130-140$ & -0.03 & 0.04 \\
\hline $\mathrm{Cu}$ & $115-120$ & $130-140$ & -0.03 & 0.01 \\
& $115-120$ & 200 & -0.03 & 0.01 \\
\hline $\mathrm{Fe}$ & $130-140$ & 200 & -0.03 & 0.03 \\
\hline 20 & $70-80$ & 0.03 & 0.04 \\
\hline $115-120$ & 160 & -0.01 & 0.05 \\
\hline $115-120$ & 200 & -0.01 & 0.02 \\
\hline $130-140$ & 200 & -0.01 & 0.05 \\
\hline $70-80$ & $115-120$ & 10.14 & 0.01 \\
\hline $70-80$ & $130-140$ & 7.40 & 0.05 \\
\hline $70-80$ & 160 & 12.00 & 0.02 \\
\hline $70-80$ & 200 & 12.00 & 0.02 \\
\hline
\end{tabular}


Table 3

Correlation between different water quality parameters with depth

\begin{tabular}{|c|c|c|c|c|c|}
\hline \multirow[t]{2}{*}{ Parameters } & \multicolumn{2}{|l|}{ Depth } & \multirow[t]{2}{*}{ Parameters } & \multicolumn{2}{|l|}{ Depth } \\
\hline & Pearson Correlation & Sig. (2-tailed) & & Pearson Correlation & Sig. (2-tailed) \\
\hline $\mathrm{pH}$ & -.284 & .348 & $\mathrm{NO}_{3}$ & -.396 & .180 \\
\hline Turbidity & .177 & .564 & $\mathrm{NO}_{2}$ & -.038 & .901 \\
\hline EC & -.447 & .126 & $\mathrm{Cr}$ & -.256 & .399 \\
\hline TDS & -.367 & .218 & $\mathrm{~Pb}$ & .307 & .307 \\
\hline COD & -.524 & .066 & Cd & -.163 & .594 \\
\hline TH & -.520 & .068 & $\mathrm{Cu}$ & .776 & .002 \\
\hline $\mathrm{Na}$ & -.438 & .134 & $\mathrm{Zn}$ & .320 & .286 \\
\hline K & .295 & .328 & $\mathrm{Fe}$ & .181 & .554 \\
\hline $\mathrm{Ca}$ & -.536 & .039 & $\mathrm{Ni}$ & -.518 & .070 \\
\hline $\mathrm{SO}_{4}$ & -.541 & .036 & $\mathrm{Mn}$ & .427 & .146 \\
\hline $\mathrm{Cl}$ & .113 & .713 & TC & -.592 & .033 \\
\hline
\end{tabular}

While analyzing the water samples it was found that $\mathrm{pH}, \mathrm{EC}, \mathrm{TDS}, \mathrm{COD}, \mathrm{TH}, \mathrm{NO}^{-3}, \mathrm{SO}_{4}{ }^{-2}, \mathrm{NO}^{-2}, \mathrm{Ca}^{+2}, \mathrm{Na}^{+}, \mathrm{TC}, \mathrm{Cr}, \mathrm{Ni}$, $\mathrm{Zn}, \mathrm{Cd}$ and TC were more in the sample collected from 70-130 feet than 140-200 feet. The percentage difference between the two is given in Fig. 4. The number of TC was assessed against the depth of sampling sources and it was found that contamination of ground water has inverse relation with depth of the source (Fig. 3). The results showed that $81.82 \%$ samples collected from ground water sources having depth less than 140 feet were found contaminated. On the other hand only $22.22 \%$ samples, collected from sources having depth of 140 feet or above, were found contaminated.

Natural filtration capability of the earth may be the possible reason for decrease in the level of contamination with increase in depth of the ground water sources. Earth layers filter the fluid when it passes through it (Kilpatrick et al., 2018). Hence, greater the travelling distance of the fluid higher will be the filtration. Therefore, the deep water sources were found safe as compared to the shallow water sources. Depending on the type of waste the including municipal solid waste, the leachate is formed and contains many contaminants which may include pathogens, organic and inorganic pollutants, toxic metals and xenobiotic organic compounds (Christensen et al., 2001; Huang et al., 2009; Joseph et al., 2020). The chemical composition of leachate is dependent on the type of waste and by published in various studies (Lü et al., 2008; Öman and Junestedt, 2008). The risk posed by the leachate containing toxic substances is the accumulation of these substances in soils and then infiltration into ground water and becoming part of the food chain when this water is consumed by the living beings (Alam et al., 2020; Ngelinkoto et al., 2014; Poté et al., 2008). Heavy metals are found to be beyond the permissible limit in the soil of landfill sites (Agbeshie et al., 2020; Essien et al., 2019; Gujre et al., 2021). The seepage from MSW landfill site has considerable impact on the quality of ground water (Singh et al., 2016). Research conducted by Yusof et al. (2009) analyzed high organic contents, $\mathrm{Cd}$ and $\mathrm{Mn}$ in the river near an active uncontrolled landfill and influences of leachate in the form of inorganic nitrogen and heavy metals such as $\mathrm{Cr}, \mathrm{Fe}, \mathrm{Mn}$ and $\mathrm{Ni}$. They observed the impacts of leachate on the nearby river. The current study also confirms that high $\mathrm{EC}$, Total hardness, $\mathrm{Na}, \mathrm{Ca}, \mathrm{NO}_{3}{ }^{-}$and $\mathrm{SO}_{4}{ }^{-2}, \mathrm{Cr}$, $\mathrm{Ni}$ and $\mathrm{TC}$ were 
observed in the samples taken from SWDS and few samples showed high turbidity and TDS. Leaching of the contaminants from the waste depends on the fixation of these contaminates in the soil and their transportation to the groundwater (Pejman et al., 2017). Raju et al. (2009) explained leaching of contaminants takes place due to permeation and percolation with rain water. As the dumping sites are open and rainy seasons are observed in the study area therefore, leaching of contaminants takes place due to the water percolation. According to a report published by UN-Habitat and UNESCAP (2012) on Mardan landfill sites; the observed sites were without soil cover and there were no compaction applied; almost 60 to 70 tons of wastes were dumped on these landfill sites. Further, there is no collection of leachate or gas from these sites. A report published by GoP (2021) reported that soil of the Mardan is "Very soft - soft to firm to stiff lean clay/silty clay/silt/ up to a depth of $7.0 \mathrm{~m}$ underlain by medium dense to very dense poorly graded sand with silt/silty sand". These facts confirm the finding of the study that the leachate percolates from the soil and contaminated the ground water. Another study conducted by Mishra et al. (2019) also showed almost same results by observing considerable amount of TDS, $\mathrm{EC}, \mathrm{NO}_{3}{ }^{-}$and $\mathrm{PO}_{4}{ }^{-3}$ in the ground water samples taken from near the landfill site thus concluding that ground water quality is significantly affected by leachate percolation. Similarly, Fernández et al. (2014) observed the impacts of leachate plume up to $900 \mathrm{~m}$ from the landfill site. As the leachate reaches the saturated zone, it forms plume which spreads in the direction of flow of water and contaminates the ground water (Vasanthi et al., 2008). The current study observes that these contaminants were more in the 70-80 feet than the 120 feet depths.

\section{Questionnaire Survey And Data Collected From The Hospitals}

According to the survey results $41 \%$ respondents suffered from diarrhea that were living at a ground leveled with MSW or 100 m within dumping sites at least once in a year. Similarly $25 \%$ suffered from typhoid and $26 \%$ suffered from skin allergies at least once in a year (Table 4). According to respondents, $18 \%$ suffered from gastro enteritis at least once in four months. The results of the questionnaire survey revealed negative correlation between the diseases and distance from the dumping site. However, significant correlation was only observed for typhoid, cholera skin allergies and gastro enteritis (Table 5). No correlation was observed between the gender and age of the respondents with diseases. 
Table 4

Frequency (Percentage) of diseases suffered by the respondents

\begin{tabular}{|c|c|c|c|c|c|}
\hline \multirow[t]{2}{*}{ Diseases } & \multirow[t]{2}{*}{ Frequency } & \multicolumn{4}{|c|}{ Distance from dumping site } \\
\hline & & $0-100 \mathrm{~m}$ & $101-400 \mathrm{~m}$ & $401-700 \mathrm{~m}$ & $701-1000 \mathrm{~m}$ \\
\hline \multirow[t]{3}{*}{ Dysentery } & $\mathrm{a}$ & 3 & 1 & 0 & 0 \\
\hline & $\mathrm{b}$ & 19 & 16 & 10 & 4 \\
\hline & c & 1 & 2 & 1 & 2 \\
\hline \multirow[t]{3}{*}{ Diarrhea } & C & 2 & 1 & 0 & 0 \\
\hline & $d$ & 4 & 3 & 0 & 1 \\
\hline & $\mathrm{e}$ & 41 & 27 & 14 & 7 \\
\hline Typhoid & $\mathrm{e}$ & 25 & 15 & 8 & 6 \\
\hline \multirow[t]{2}{*}{ Ringworm } & $\mathrm{d}$ & 15 & 6 & 3 & 4 \\
\hline & e & 0 & 1 & 0 & 0 \\
\hline \multirow[t]{3}{*}{ Cholera } & c & 5 & 1 & 0 & 1 \\
\hline & $d$ & 15 & 8 & 5 & 5 \\
\hline & $\mathrm{e}$ & 2 & 4 & 0 & 2 \\
\hline \multirow[t]{2}{*}{ Malaria } & $d$ & 18 & 15 & 6 & 4 \\
\hline & $\mathrm{e}$ & 4 & 1 & 1 & 1 \\
\hline Gastro & $\mathrm{b}$ & 18 & 10 & 1 & 3 \\
\hline \multirow[t]{3}{*}{ Enteritis } & C & 25 & 15 & 7 & 3 \\
\hline & $d$ & 10 & 1 & 0 & 0 \\
\hline & $\mathrm{e}$ & 4 & 1 & 0 & 2 \\
\hline \multirow[t]{5}{*}{ Skin Allergies } & $\mathrm{a}$ & 1 & 1 & 0 & 2 \\
\hline & $\mathrm{b}$ & 0 & 0 & 1 & 0 \\
\hline & c & 12 & 2 & 4 & 2 \\
\hline & $d$ & 26 & 21 & 8 & 3 \\
\hline & $\mathrm{e}$ & 8 & 7 & 1 & 1 \\
\hline
\end{tabular}


Table 5

Correlation between distance from dumping sites and diseases suffered by the respondents

\begin{tabular}{|lllllllll|}
\hline & Diarrhea & Dysentery & Typhoid & Ringworm & Cholera & Malaria & $\begin{array}{l}\text { Skin } \\
\text { Allergies }\end{array}$ & Gastro \\
\hline $\begin{array}{l}\text { Pearson } \\
\text { Correlation }\end{array}$ & -.150 & -.063 & $-.349^{\star *}$ & -.116 & $-.206^{*}$ & -.073 & $.279^{* *}$ & $-.328^{* *}$ \\
\hline Sig. (2-tailed) & .035 & .533 & .000 & .248 & .039 & .470 & .005 & .001 \\
\hline
\end{tabular}

As consumption of the contaminated water may pose health risk to the local community due to bacteriological contamination and this is among the major threats to drinking water and ultimately to human health (Azizullah et al., 2011). To assess the health risk to the locals due to consumption of contaminated drinking water, waterborne diseases data were collected from the DHQ hospital Mardan. Though, in Pakistan proper assessment and quantification of water borne diseases is a hard job due to lack of record maintenance at hospitals (Aziz, 2005). The data collected from the DHQ hospital revealed that the residents of SWDS suffered frequently from diarrhea, dysentery, typhoid and skin diseases. According to the hospital sources approx. 2500 patients/ day were visiting outpatient department (OPD), out of which $22 \%$ suffered from waterborne diseases. During the rainy seasons this percentage raised to $35-40 \%$ of the total patients attending OPDs wherein almost $75 \%$ were from the regions of SWDS. This high burden of waterborne diseases in the study area confirmed that the ground water sources of the study area were not safe. Similar results were reported by the United Nations International Children's Emergency Fund (UNICEF) that waterborne diseases are responsible for about 20 to $40 \%$ of all the patients in hospitals of Pakistan among which typhoid, giardiasis, cryptosporidiosis, dysentery, cholera and other gastrointestinal problems accounts for one third of all deaths in the country.

\section{Conclusion}

In this study, samples were collected from sites leveled with solid waste and compared with the samples of safe zone. The results showed that level of contamination was comparatively much higher in the solid waste dumping sites samples. Questionnaire survey and hospital data also confirmed the negative health impacts of the contaminated water. Thus, it can be concluded form the study that the use of MSW for leveling of residential lands is not safe and this practice has contaminated the ground water of the study area. Therefore, this practice should be discouraged and the concerned government departments shall play their role to ensure human health safety and to avoid any potential risk. To minimize health risk, deep drilling should be done for extraction of ground water. Regular monitoring of ground water sources in the study area is recommended.

\section{Declarations}

\section{Ethics approval and consent to participate}

Not applicable

\section{Consent for publication}

Not applicable

\section{Consent to Publish}

Not applicable 
All data generated or analyzed during this study are included in this published article.

\section{Competing interests}

"The authors declare that they have no competing interests".

\section{Funding}

Not applicable

\section{Authors' contributions}

Dr. Israr and Dr. Hizbullah contributed to the study conception and design. Field survey and lab analysis was performed by Dr. Israr. Questionnaire was prepared by Dr. Ali Raza and Dr. Shahla and questionnaire survey was also conducted by Dr. Jawad. The first draft of the manuscript was written by Dr. Shahla Nazneen and Dr. Israr. Figures and graphs were prepared by Dr. Shahla and Dr. Neelum. Data analysis and statistical techniques were applied by Dr. Shahla Nazneen and Dr. Sardar Khan. All the associated health risk assessment was conducted by Dr. Ali Raza. All authors discussed the results and approved the final manuscript.

\section{References}

1. Agbeshie, A.A., Adjei, R., Anokye, J. and Banunle, A., 2020. Municipal waste dumpsite: impact on soil properties and heavy metal concentrations, Sunyani, Ghana. Scientific African, 8: e00390.

2. Al-Sabahi, E., Rahim, S.A., Wan Zuhairi, W., Al-Nozaily, F. and Alshaebi, F., 2009. The characteristics of leachate and groundwater pollution at municipal solid waste landfill of Ibb City, Yemen. American Journal of Environmental Sciences, 5(3): 256-266.

3. Alam, P., Sharholy, M. and Ahmad, K., 2020. A study on the landfill leachate and its impact on groundwater quality of Ghazipur area, New Delhi, India, Recent Developments in Waste Management. Springer, pp. 345-358.

4. Aziz, J., 2005. Management of source and drinking-water quality in Pakistan. EMHJ-Eastern Mediterranean Health Journal, 11 (5-6), 1087-1098, 2005.

5. Azizullah, A., Khattak, M.N.K., Richter, P. and Häder, D.-P., 2011. Water pollution in Pakistan and its impact on public health-a review. Environment international, 37(2): 479-497.

6. Beffa, T., Blanc, M., Marilley, L., Fischer, J.L., Lyon, P.-F. and Aragno, M., 1996. Taxonomic and metabolic microbial diversity during composting, The science of composting. Springer, pp. 149-161.

7. Chonattu, J., Prabhakar, K. and Pillai, H.P.S., 2016. Geospatial and statistical assessment of groundwater contamination due to landfill leachate-a case study. Journal of Water Resource and Protection, 8(2): 121-134.

8. Christensen, T.H., Kjeldsen, P., Bjerg, P.L., Jensen, D.L., Christensen, J.B., Baun, A., Albrechtsen, H.-J. and Heron, G., 2001. Biogeochemistry of landfill leachate plumes. Applied geochemistry, 16(7-8): 659-718.

9. Essien, J.P., Inam, E.D., Ikpe, D.I., Udofia, G.E. and Benson, N.U., 2019. Ecotoxicological status and risk assessment of heavy metals in municipal solid wastes dumpsite impacted soil in Nigeria. Environmental Nanotechnology, Monitoring \& Management, 11: 100215.

10. Farid, S., Baloch, M.K. and Ahmad, S.A., 2012. Water pollution: Major issue in urban areas. International journal of water resources and environmental engineering, 4(3): 55-65. 
11. Farooq, S., Hashmi, I., Qazi, I.A., Qaiser, S. and Rasheed, S., 2008. Monitoring of coliforms and chlorine residual in water distribution network of Rawalpindi, Pakistan. Environmental monitoring and assessment, 140(1-3): 339347.

12. Fernández, D.S., Puchulu, M.E. and Georgieff, S.M., 2014. Identification and assessment of water pollution as a consequence of a leachate plume migration from a municipal landfill site (Tucumán, Argentina). Environmental geochemistry and health, 36(3): 489-503.

13. GoP, 2021. Pakistan: Khyber Pakhtunkhwa Cities Improvement Project: Mardan Solid Waste Management Facility Development.

14. Gujre, N., Mitra, S., Soni, A., Agnihotri, R., Rangan, L., Rene, E.R. and Sharma, M.P., 2021. Speciation, contamination, ecological and human health risks assessment of heavy metals in soils dumped with municipal solid wastes. Chemosphere, 262: 128013.

15. Hassan, M., 2016. Water security in Pakistan: Issues and challenges. United Nations Development programme Pakistan, 3.

16. Huang, J.-H., Ilgen, G., Vogel, D., Michalzik, B., Hantsch, S., Tennhardt, L. and Bilitewski, B., 2009. Emissions of inorganic and organic arsenic compounds via the leachate pathway from pretreated municipal waste materials: a landfill reactor study. Environmental science \& technology, 43(18): 7092-7097.

17. IARC, 2018. Chromium (IV) Compounds. IARC Monograph 100C.

18. Joseph, S., Wijekoon, P., Dilsharan, B., Punchihewa, N., Athapattu, B. and Vithanage, M., 2020. Anammox, biochar column and subsurface constructed wetland as an integrated system for treating municipal solid waste derived landfill leachate from an open dumpsite. Environmental Research, 189: 109880.

19. Khan, K., Lu, Y., Saeed, M.A., Bilal, H., Sher, H., Khan, H., Ali, J., Wang, P., Uwizeyimana, H. and Baninla, Y., 2018. Prevalent fecal contamination in drinking water resources and potential health risks in Swat, Pakistan. Journal of Environmental Sciences, 72: 1-12.

20. Kilpatrick, J., Marcum-Dietrich, N., Wallace, J. and Staudt, C., 2018. Engineering a Model of the Earth as a Water Filter. Science and Children, 56(3): 73-77.

21. Kumar, D. and Alappat, B.J., 2005. Evaluating leachate contamination potential of landfill sites using leachate pollution index. Clean Technologies and Environmental Policy, 7(3): 190-197.

22. Leoni, E., De Luca, G., Legnani, P., Sacchetti, R., Stampi, S. and Zanetti, F., 2005. Legionella waterline colonization: detection of Legionella species in domestic, hotel and hospital hot water systems. Journal of Applied Microbiology, 98(2): 373-379.

23. Lü, F., Zhang, H., Chang, C.-H., Lee, D.-J., He, P.-J., Shao, L.-M. and Su, A., 2008. Dissolved organic matter and estrogenic potential of landfill leachate. Chemosphere, 72(9): 1381-1386.

24. Mishra, S., Tiwary, D., Ohri, A. and Agnihotri, A.K., 2019. Impact of Municipal Solid Waste Landfill leachate on groundwater quality in Varanasi, India. Groundwater for Sustainable Development, 9: 100230.

25. Mohsenizadeh, M., Tural, M.K. and Kentel, E., 2020. Municipal solid waste management with cost minimization and emission control objectives: A case study of Ankara. Sustainable Cities and Society, 52: 101807.

26. Mor, S., Ravindra, K., Dahiya, R. and Chandra, A., 2006. Leachate characterization and assessment of groundwater pollution near municipal solid waste landfill site. Environmental monitoring and assessment, 118(13): 435-456.

27. Muhammad, S., Shah, M.T. and Khan, S., 2010. Arsenic health risk assessment in drinking water and source apportionment using multivariate statistical techniques in Kohistan region, northern Pakistan. Food and Chemical Toxicology, 48(10): 2855-2864. 
28. Ngelinkoto, P., Thevenon, F., Devarajan, N., Birane, N., Maliani, J., Buluku, A., Musibono, D., Mubedi, J.I. and Poté, J., 2014. Trace metal pollution in aquatic sediments and some fish species from the Kwilu-Ngongo River, Democratic Republic of Congo (Bas-Congo). Toxicological \& Environmental Chemistry, 96(1): 48-57.

29. Öman, C.B. and Junestedt, C., 2008. Chemical characterization of landfill leachates -400 parameters and compounds. Waste management, 28(10): 1876-1891.

30. Pejman, A., Bidhendi, G.N., Ardestani, M., Saeedi, M. and Baghvand, A., 2017. Fractionation of heavy metals in sediments and assessment of their availability risk: A case study in the northwestern of Persian Gulf. Marine pollution bulletin, 114(2): 881-887.

31. Poté, J., Haller, L., Loizeau, J.-L., Bravo, A.G., Sastre, V. and Wildi, W., 2008. Effects of a sewage treatment plant outlet pipe extension on the distribution of contaminants in the sediments of the Bay of Vidy, Lake Geneva, Switzerland. Bioresource Technology, 99(15): 7122-7131.

32. Raju, N.J., Ram, P. and Dey, S., 2009. Groundwater quality in the lower Varuna river basin, Varanasi district, Uttar Pradesh. Journal of the Geological Society of India, 73(2): 178-192.

33. Raju, N.J., Shukla, U. and Ram, P., 2011. Hydrogeochemistry for the assessment of groundwater quality in Varanasi: a fast-urbanizing center in Uttar Pradesh, India. Environmental monitoring and assessment, 173(1-4): 279-300.

34. Rijsberman, F.R., 2006. Water scarcity: fact or fiction? Agricultural water management, 80(1-3): 5-22.

35. Shar, A.H., Kazi, Y.F. and Soomro, I.H., 2008. Impact of seasonal variation on bacteriological quality of drinking water. Bangladesh Journal of Microbiology, 25(1): 69-72.

36. Singh, S., Raju, N.J., Gossel, W. and Wycisk, P., 2016. Assessment of pollution potential of leachate from the municipal solid waste disposal site and its impact on groundwater quality, Varanasi environs, India. Arabian Journal of Geosciences, 9(2): 131.

37. Somani, M., Datta, M., Gupta, S., Sreekrishnan, T. and Ramana, G., 2019. Comprehensive assessment of the leachate quality and its pollution potential from six municipal waste dumpsites of India. Bioresource Technology Reports, 6: 198-206.

38. Tang, Z., Li, W., Tam, V.W. and Xue, C., 2020. Advanced progress in recycling municipal and construction solid wastes for manufacturing sustainable construction materials. Resources, Conservation \& Recycling: X, 6 : 100036.

39. Tufail, M., Asghar, M., Akram, M., Javied, S., Khan, K. and Mujahid, S., 2013. Measurement of natural radioactivity in soil from Peshawar basin of Pakistan. Journal of Radioanalytical and Nuclear Chemistry, 298(2): 1085-1096.

40. UN-Habitat and UNESCAP, 2012. Baseline Study for SWM in Mardan Pakistan.

41. Usmani, Z., Kumar, V., Varjani, S., Gupta, P., Rani, R. and Chandra, A., 2020. Municipal solid waste to clean energy system: A contribution toward sustainable development, Current Developments in Biotechnology and Bioengineering. Elsevier, pp. 217-231.

42. Vasanthi, P., Kaliappan, S. and Srinivasaraghavan, R., 2008. Impact of poor solid waste management on ground water. Environmental monitoring and assessment, 143(1): 227-238.

43. Yusof, N., Haraguchi, A., Hassan, M., Othman, M., Wakisaka, M. and Shirai, Y., 2009. Measuring organic carbon, nutrients and heavy metals in rivers receiving leachate from controlled and uncontrolled municipal solid waste (MSW) landfills. Waste Management, 29(10): 2666-2680.

\section{Figures}

Page $14 / 18$ 


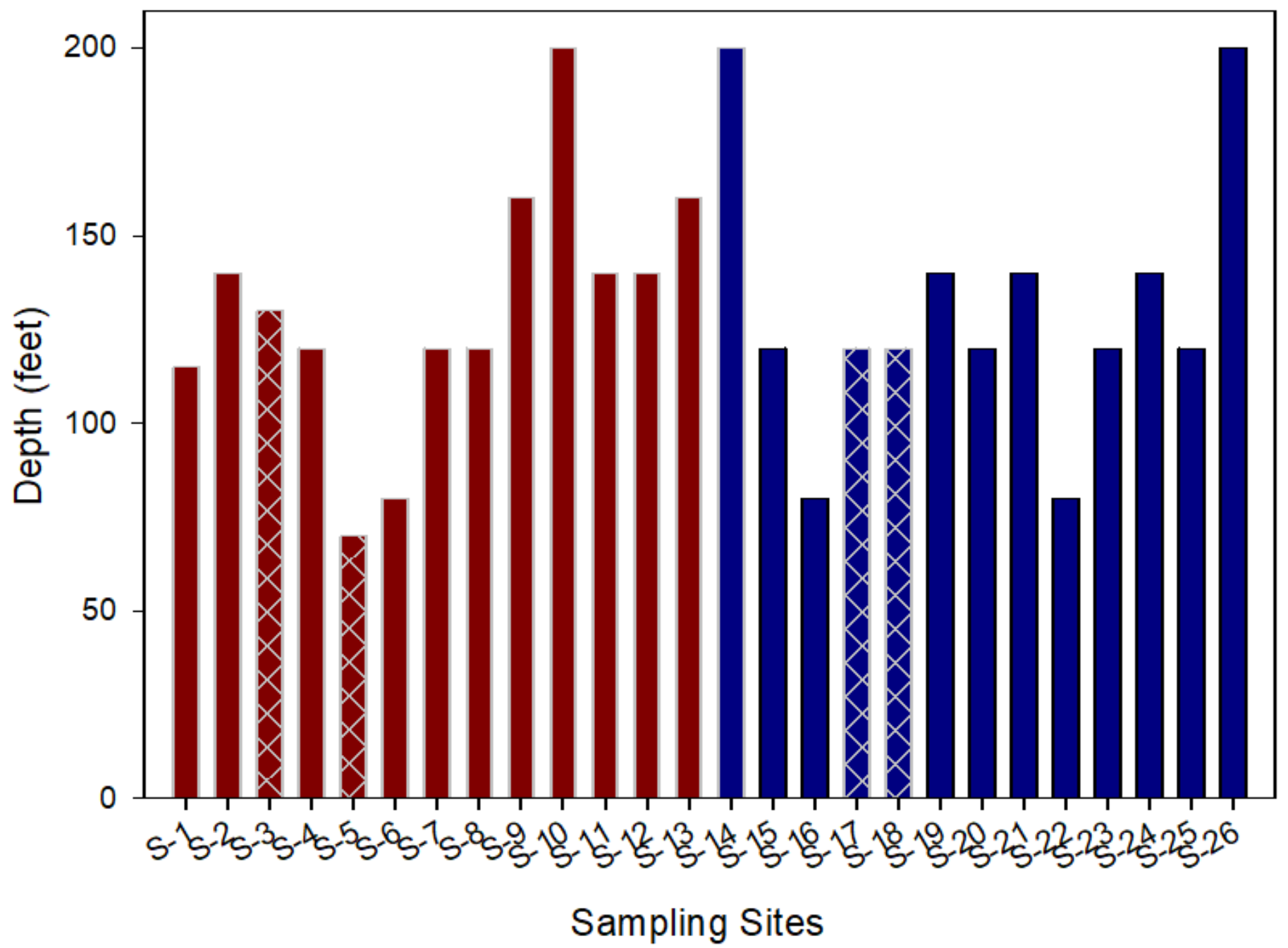

Figure 1

Sampling sites; Red bars shows samples collected from SWDS and Blue bars shows samples collected from SS; Clean bars shows samples collected from pressure pumps and pattern bars show sample collected from hand pumps 


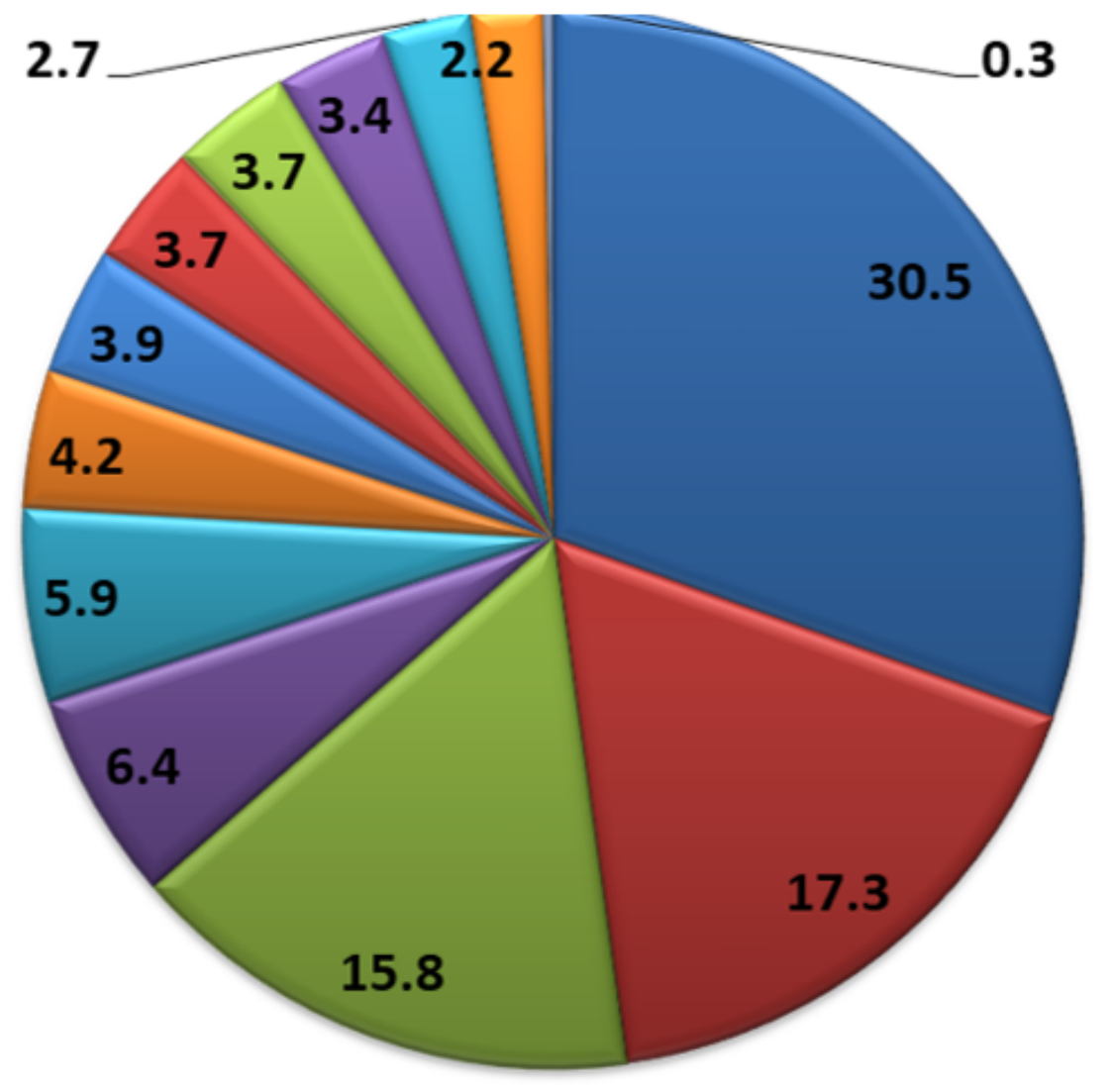

a Food and garden waste

a Fine

$\square$ Others

Q Inert

- Leather and non recyclable Plastics

$\square$ Complex Products

- Plastics and rubbers

口Glass

$\square$ Textitle and rugs

- Paper and Card board

$\square$ Wood

$\square$ Health care waste

$\square$ Metals

Figure 2

Categorization of the waste dumped at SWDS (in percentage) 


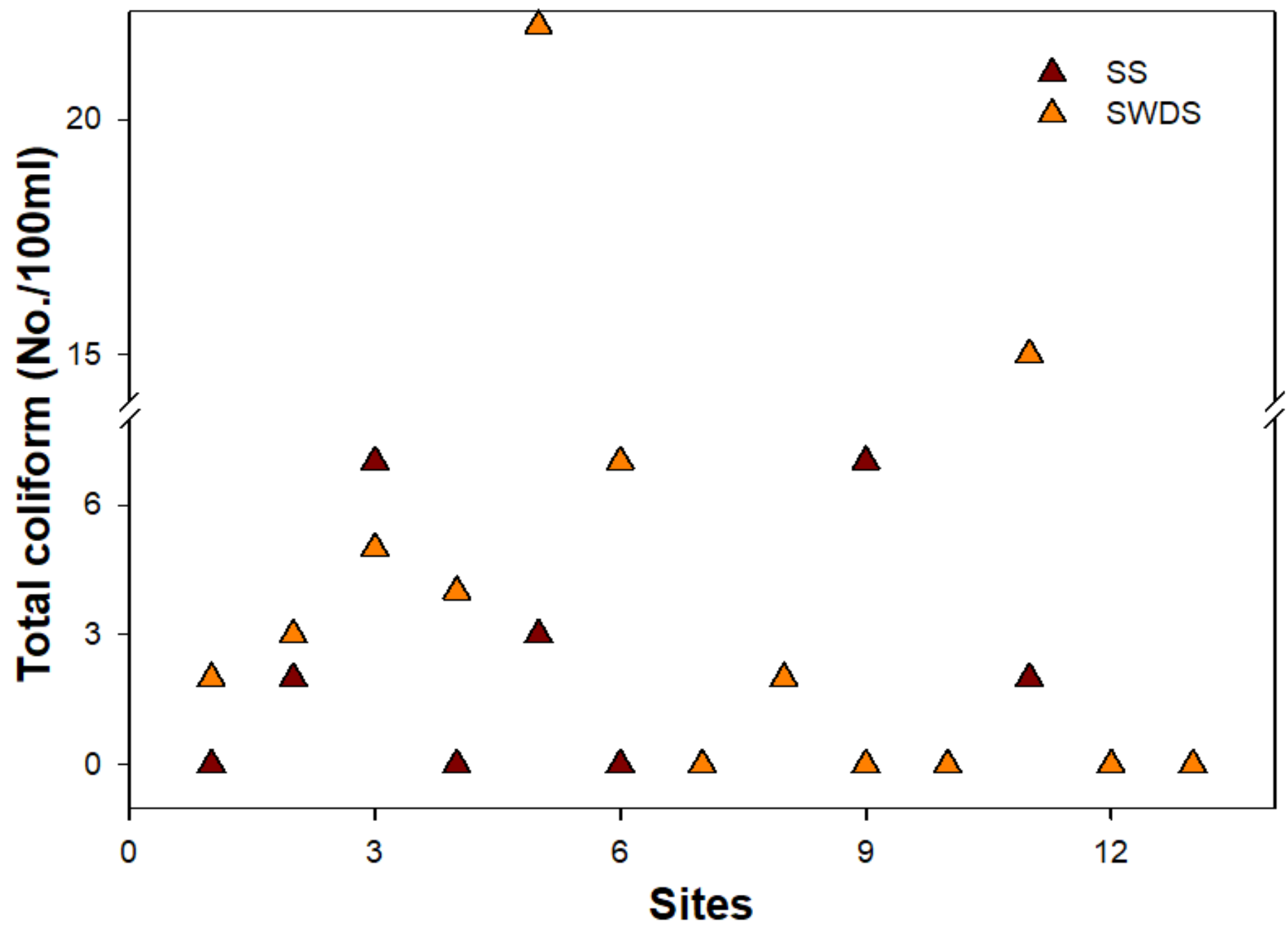

Figure 3

Total coliform in the samples collected from SWDS and SS 


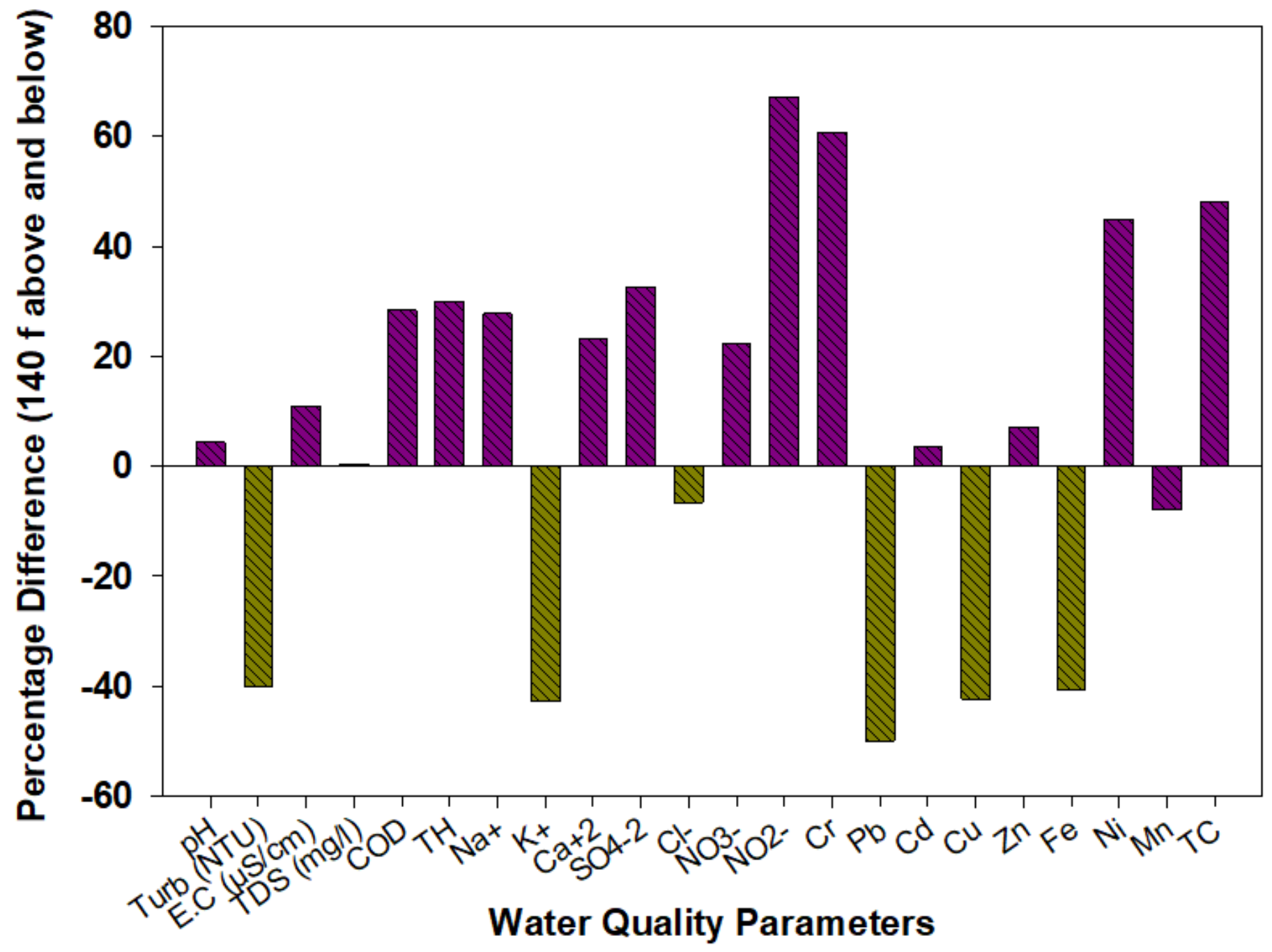

Figure 4

Percentage difference between water quality parameters in drinking water (140 f below and above) 